\title{
The Impact of the Social Media on the Academic Performance of Secondary School Students in Benin Metropolis
}

Imasuen Kennedy*

Institute of Education, University of Benin, Benin City, Nigeria

\author{
DOI: 1 10.36348/jaep.2020.v04i07.005 $\quad$ | Received: 26.06 .2020 | Accepted: 03.07.2020 | Published: 28.07 .2020 \\ *Corresponding author: Kennedy Imasuen
}

Abstract

Social media have changed the way people interact and communicate in the world today. This study examines the impact of the social media on the academic Performance of Secondary School Students in Benin Metropolis of Edo State. The descriptive survey method was adopted, the population comprises of all senior secondary school students in Benin Metropolis. Five hundred and seventy five students from twenty three public secondary schools in Benin Metropolis were randomly sampled. The questionnaire was the instrument of data collection. The data were analyzed using frequency counts, mean and standard deviation. The hypotheses were tested using the independent sample t -test. Finding shows amongst others that the secondary school students have access to social media and spend at least five hours daily; and that their exposure to social media is to a high degree. Their exposure to social media has effect on the students' academic performance positively and that there are dangers in the exposure of secondary school students to the social media. To this end, the study recommends that students should be enlightened to pay minimal attention to social media and use it more for academic activities.

Keywords: Social media; academic performance, networking site.

Copyright @ 2020: This is an open-access article distributed under the terms of the Creative Commons Attribution license which permits unrestricted use, distribution, and reproduction in any medium for non-commercial use (NonCommercial, or CC-BY-NC) provided the original author and sources are credited.

\section{INTRODUCTION}

The evolution of technology has brought rapid changes to the world. Modern Technology in communication no doubt has turned the entire world into a "Global village". The world of today is celebrating the advancement in communication technology which has broadened the scope of communication through Information and Communication Technologies (ICTs). Technology has exposed mankind to a better way of solving problems. Social networking sites include: Twitter, Yahoo Messenger, Facebook Messenger, Blackberry Messenger (BBM), Whats app messenger, 2go messenger, Skype, Google talk, Google Messenger, iPhone and Androids. These networking sites are used by most people to interact with old and new friends, physical or internet friends [1]. It helps people to be better informed, enlightened, and keeping abreast with world developments. Technology exposes mankind to a better way of doing things. This has resulted into the use of technology as the best medium to explore the wide area of knowledge.

The evolution of internet technology has led to its use as the best medium for communication.
Whereby, two-third of the world's internet population visits social networking or blogging sites, thus serving as a communication and connection tool. These networking sites are referred to as social media [2].

Social networking sites (SNSs) are online Communities of Internet users, who want to communicate with other users about areas of mutual interest, whether from a personal, business or academic perspective [3]. The millions of social networking sites have transformed the thought of global village into a reality whereby billions of people communicate through social networking sites. Numerous benefits have been obtained through distant communication through the use of social networking sites.

Social media is a phrase being used a lot. It is a website that doesn't just give you information but interact with you while giving you information. Social media is that means that employs mobile and web based technology to create highly interactive platforms via which individuals and community share, co-create, discuss and modifies user-generated content [4]. According to the Meriam-Webster dictionary, "Social media is forms of electronic communication through 
which users create online communities to share information, idea, personal message and other content".

Kaplan and Haenlein [5] classified social media into six different classes as follows: Collaborative projects; Blogs and micro blogs; Content communities; Social Networking sites; Virtual Game World and Virtual Social World.

\section{Collaborative Project}

These are social media platforms where any participant or user is allowed to modify any page or create a new page using her web browser. An example of a collaborative project is Wikipedia.

Wikipedia is a project owned by the Nonprofit Wikimedia Foundation. Wikipedia was launched on the $15^{\text {th }}$ of January 2001 by Jimmy Wales and Larry Sanger.

\section{Micro-Blogging Sites}

Micro blogging sites are social media platforms which allows users write brief texts update and publish them on the platform. Example of a microblogging site is Twitter

Twitter was founded on the $21^{\text {st }}$ of March 2006 by Jack Dorsey and Noah Glass. Twitter is an online social networking site that enables its users to send and read text-based posts. From the conception, these texts were limited to 140 text characters but on November 7 2017, the limit was doubled to 280 characters. These texts are known as "tweets'. Users also follow the updates of friends they "follow", send them direct messages, and reply publicly to friends, or just post questions or comments as their current status [6]. Twitter as a social network plays a role in communication throughout the world in the sense providing online services to share information with others and connect with them by creating a profile that may include a personal web page and a blog.

\section{Content Communities}

Content communities also known as Media sharing sites are social media platforms that allow users to post videos or photographs that can be accessed from anywhere around the world. Instagram is a popular but not the only media sharing sites.

Instagram was founded on the $6^{\text {th }}$ of October 2010 by Kevin Systrom and Mike Krieger. Instagram allows registered users upload photos or videos to their pages.

\section{Social Networking Sites}

Social networking sites are used to describe any website that enables users to create public profiles within that website and form relationship with other users of the same website who access their profile. It is used to describe community based websites, online discussion forum, chat rooms and other social space online. Ellison and Boyd [2] define social networking sites as web-based services that allow individuals to construct profiles, display user connections and search and traverse within that list of connections. It is a website that allows users to share information within a selected group. It is a great way to stay connected, and a convenient way to share photos from trips [7]. An example of a social networking site is Facebook.

Facebook is a social networking site founded by Mark Zuckerberg. It was launched on the $4^{\text {th }}$ of April, 2004. Facebook allows anyone who claims to be at least 13 years of age to become a registered user of the site. Users must register before using the site, after which they may create a personal profile, add other users as friends, exchange messages, and receive automatic notifications when they update their profile [8]. Additionally, users may join common-interest user groups, organized by workplace, school or college, or other characteristics, and categorize their friends into lists such as "people from work" or "close friends" [9].

\section{Virtual Game World}

Virtual game world are platforms that replicates a three-dimensional environment in which users can appear in the form of personalized avatars and interact with each other as they would in real life [5]. An example of a virtual game world media is the World of War craft.

\section{Virtual social World}

The second group of virtual world often referred to as virtual social worlds, allow inhabitants to choose their behavior more freely and essentially live a virtual life similar to their real life [5]. The difference between these two game worlds is that the second world has $n$ rules restricting the range of interactions, except for basic physical law such as gravity. An example of a virtual social world is the second life application founded by San Francisco based company. These categories of social media however overlap to some degree. Twitter for example, is a social network site as well as a blog. Likewise, users of the social networking site Facebook can share photographs and users of the media sharing site can follow other people.

Academic excellence or achievement plays an important role in an individual placement, be it in the academic institutions or job placement. Due to this, many people are concerned with the ways they can enhance their academic achievement. The emphasis on academic excellence which is also prevalent worldwide has encouraged many studies about the conditions promoting it. The role of academic achievement as one of the predictors of one's life success and also in the aspect of academic placement in schools to higher institutions as well as the level of employability in one's career is inevitable [10]. 
Academic performance, measured by the evaluation of results is one of the major goals of a school. Hoyle [11] argued that schools are established with the aim of imparting knowledge and skills to those who go through them and behind all this is the idea of enhancing good academic performance. A direct relationship exists between Social media usage and the academic performance of students. However, the darker side within technological evolution has resulted in dilemmas such as the setback of real values of life especially among students who form the majority of users interacting through the use of social networking sites. Online social media sites focus on building and reflecting social associations among people who share interests. With so many social media sites displayed on the internet, students are tempted to abandon their home activities and reading times in preference for chatting online with friends. Many students are now addicted to the online rave of the moment, with Instagram, Facebook, Twitter etc.

Today most youths and students possess various social media site. The reason most of them perform badly in school might not be far- fetched.

Social media became hugely common and well-known in past few years. Students' addictiveness and exposure to social networks, its influence as a medium of interaction between students, and its impact on their academic performance has been part of the discussion in recent times. Instead of students reading their books, they spend their time chatting and making friends via social media and this might definitely have influence on their academic performance, because when you do not read, there is no way you can perform well academically. It is a common sight to see a student chatting in sensitive and highly organized places like church, mosque and lecture venues. Some are so carried away that even as they are walking along the high way, they keep chatting.

It's a group of internet based application that allows the creation and exchange of users generated content. Often times, social media is confused with social news because members of the news are referred to as media, and also social news site is also social media site. Andreas and Michael [12] are of the opinion that social media is a group of internet based application that builds on the ideological foundation and allows the creation and exchange of users generated content. Social media has become one of the major channels of chatting through platforms such as blogger and Blackberry chat. The internet usage effect of social media, in views of Nelson [13] is that, students continue to spend more time on the social media than any site.

Having social media in the classroom has been a controversial topic for the last several years. Many parents and educators have been fearful of the repercussions of having social media in the classroom
[14]. As a result, cell phones have been banned from classroom and schools have blocked many popular social media websites. However, despite adult's apprehensions, students are using social media. Schools have realized that they need to incorporate these tools into the classroom and rules are changing.

Facebook represents a potentially useful tool in educational contexts. It allows for both an asynchronous and synchronous, open dialogue via a familiar and regularly accessed medium, and supports the integration of multimodal content such as studentcreated photographs and video and Uniform Resources Locator (URLs) to other texts, in a platform that many students are already familiar with. It also allows students to manage their own privacy settings, and often work with the privacy settings they have already established as registered users.

Facebook is one alternative means for shyer students to be able to voice their thoughts in and outside of the classroom. It allows students to collect their thoughts and articulate them in writing before committing to their expression. Further, the level of informality typical to Facebook can also aid students in self-expression and encourage more frequent studentand-instructor and student-and-student communication.

Twitter also promotes social connections among students. It can be used to enhance communication building and critical thinking. Students reportedly used Twitter to connect with content and other students.

YouTube is the most frequently used social media tool in the classroom [15]. Students can watch videos, answer questions, and discuss content. Additionally, students can create videos to share with others. Sherer and Shea [16] claimed that YouTube increased participation, personalization (customization), and productivity. YouTube also improved students' digital skills and provided opportunity for peer learning and problem solving. Eick and King [17] found that videos kept students' attention, generated interest in the subject, and clarified course content.

Social media networks, as well as other new forms of communication technology, are also a concern to many school professionals because of the level of distraction they create within the school [18]. Even though many schools have created many strict rules that forbid the use of handheld technology during school activities or that block certain social networking websites, many students are still able to connect during lecture hours as they please [18]. This has caused distractions during instruction time and has had a negative impact on the learning environment. Olubiyi [19] noted that these days' students are so engrossed in the social media that they are almost 24 hours online. Even in classrooms and lecture theatres, it has been 
Imasuen Kennedy., J Adv Educ Philos, July, 2020; 4(7): 334-343

observed that some students are always busy pinging, blogging, vlogging or Facebooking, while lectures are on. Times that ought be channeled towards learning, academic research and innovation, have been crushed by the passion for meeting new friends online, and most times busy discussing trivial issues. Hence most students' academics suffer setback as a result of distraction from the social media. Obi, Bulus, Adamu \& Sala'at [20], observed that the use of these sites also affects students' use of English and grammar. The students are used to short forms of writing words in their chat rooms; they forget and use the same in the classrooms. They use things like 4 in place of for, $U$ in place of You, D in place of The etc. and this could affect their class assessment.

According to Deng and Tavares [21], social media help students to think clearly and this helps them to make wise decisions in their day-to-day lives. The study conducted by Apeanti and Danso [22], revealed that students felt that their grades would be better if they can contact professors openly through social media to get their doubts clarified. Yunus and Salehi [23] pointed out that, social media use enhanced students' vocabulary and writing ability.

However, Paul, Baker and Cochran [24], opined that the time spent on social media was dependent on the attention span of the students. Attention span according to them is the amount of time for which students can concentrate on their study without getting distracted. They found out that, higher the attention span, lower is the time spent by students on social media. On his part, Junco [25], posited that time spent on Facebook was very strongly negatively related to the overall GPA of the students. Kirschner and Karpinski [26] found out that, over indulgence with social media can affect students' academic performance negatively.

Mingle and Adams [27], in their study on the social media effect on grade performance, Likert scale was used to survey amongst 526 students. Out of these 526 students, majority confirmed that the use of social media affected their grades negatively. 62 (11.8\%) students strongly agreed, while a majority of students of strength $255(48.5 \%)$ agreed that their grades dropped owing to the use of social media. In addition, 60 $(11.4 \%)$ students neither agreed nor disagreed. Finally, (8.2\%) and $106(20.2 \%)$ students disagreed and strongly disagreed respectively that their grades dropped, due to the use of social media.

Davies and Cranston [28], enumerated some of the risks associated with social media which included criminal activities such as identity theft and fake contacts which is prevalent today, sexual abuse or harassment and unsuitable advertising. On the same subject O'keeffe and Clakepearson [29], also mentioned cyberbullying, online harassment, sexting, face book depression, and privacy concerns as some of the challenges associated with social networking.

Studies have shown that boys have been online more than girls in previous decades because of earlier forms of technology such as video or computer games [30]. Girls have reported that they use social media for things like chatting and downloading music [31]. Because of this, one may hypothesize that girls will be more likely to be attracted to social media networks and other online social groups [31]. According to most research done on the topic, the number of teenage girls and boys who communicate on these social media networks are equally divided [32].

Research has shown that though girls and boys are both likely to have a Social Networking Site account, the reasons for the accounts may vary based on gender [32]. For girls, social networking sites are primarily placed to reinforce pre-existing friendships; for boys, the networks also provide opportunities for flirting and making new friends [32]. Girls are also more likely than boys to post sexually explicit pictures of themselves, and to talk about sexual activity in public forums [33]. However, boys are more likely to create an account simply because they are trying to meet a significant other, or because they are already in a relationship with someone who has requested them to join [32].

Girls are also more likely than boys to share personal information about their daily lives [34]. Results of a recent study involving Facebook showed that though most teenagers aged 13-17 used these sites for fun and positive reasons, 55\% of girls shared personal stories about depression, anxiety, and relationship problems, only $15 \%$ of boys shared any personal information besides their hobbies, interests, and friendships [34].

Peter and Valkenburg [35], in their study was shown that boys seem to benefit more from social media use and communication technology than girls do.

The early stages of social networking, as mentioned earlier, included web technology such as AIM, which helped many "chat" with others on the computer rather than in person [35]. The number of teenagers, both male and female, participating on social networking sites is staggering, and this may explain why certain problems arise from these sites that have become a major problem in today's society.

The manufacturing and distribution of equally sophisticated cellular phones has complicated the situation, as students no longer need to visit a cybercafé before they send and receive messages. Attention has been shifted from visible to invisible friends, while important ventures like study and writing might be affected in the process. This phenomenon has become a 
source of worry to many who believe in knowledge and skill acquisition.

\section{Statement of Problem}

In recent times social media have been a major stay in the minds of students and the world at large thereby causing a lot of drastic measure by students, teacher and even educational administrators. It is therefore of great importance to explore some of the trending issues facing students' academic performance as a result of social media. Students at all levels of learning now have divided attention to studies, as a result of available opportunities to be harnessed from social media. Whether these opportunities promote studies is a question that needs to be answered. Thus, the problem this study investigates is the influence of social media networks on the academic performance of the secondary school students in Benin Metropolis of Edo state.

\section{Purpose of the Study}

The purpose of this study is to examine the influence of Social Media on the Academic Performance of secondary school students in Benin Metropolis of Edo State. Specifically, this study seeks;

1. To determine the social media network that the students are more exposed to.

2. To determine how the use of social media has influence the academic performance of the secondary school students in Benin Metropolis of Edo State.

\section{Research Questions}

The following research questions were raised to guide the study

1. To what extent does social network influences the academic performance of secondary school students in Benin Metropolis of Edo State?

2. What are the dangers in secondary student's exposure to social media?

3. How many hours do students spend daily on social media?

\section{Research Hypotheses}

1. There is no significant difference in the academic performance of students who use the social media and those who do not in Benin Metropolis of Edo State.

2. There is no significant difference between male and female student usage of social media network.

\section{Significance of the Study}

This study will help the teachers of the school to ascertain the influence that social media has on their students, so as to assist them to enlighten and create awareness to the students on the possible influence it has on them. The study is of significance to parents in the sense that they will know the possible effects these social media usage has on their children, so as to serve as watch-dog to their children on the usage of the social networking site. The study will also enable the students to be aware that, apart from the social benefits of social networking site, using the sites more than necessary will pose possible dangers to their health. It will be relevant in assisting students in understanding the diversity of social media.

\section{METHODOLOGY}

This study used the descriptive survey research design. The population of the study consists of all senior secondary school students in Benin Metropolis of Edo state.

Twenty three public Senior Secondary school in Benin Metropolis of Edo State were randomly selected for the use of the study. Twenty five students in each of the selected schools were randomly selected to give the total of five hundred and seventy five students which formed the sample size for the study. The instrument used for data collection is questionnaires, it consist of thirty items designed to access the impact of social media on secondary school students using the four point Likert scale. The instrument was validated by experts in measurement and evaluation. The Cronbach alpha reliability statistics was used, and gave an acceptable value of $\alpha=0.87$. The data collected were analyzed using frequency counts mean and standard deviation. A mean criterion value of 2.50 which is the arithmetic mean of the weight assigned to the four point Likert scale was used for acceptance. The hypotheses were tested using the Independent Sample $\mathrm{t}$ - test, and were tested at 0.05 level of significance.

\section{RESULTS}

Research question 1: To what extent does social network influences the academic performance of secondary school students in Benin Metropolis of Edo State? 
Imasuen Kennedy., J Adv Educ Philos, July, 2020; 4(7): 334-343

Table-1: Mean ratings of the influence social network in the academic performance of secondary school students in Benin Metropolis of Edo State

\begin{tabular}{|l|c|l|l|}
\hline Items & Mean & $\begin{array}{l}\text { Standard } \\
\text { deviation }\end{array}$ & Remarks \\
\hline Social media improves students academically & 3.13 & .71 & Agree \\
\hline Social media enlightens students more about what is been taught in class & 2.86 & .95 & Agree \\
\hline Shy students use social media as an alternative means to voice their thoughts & 3.09 & .83 & Agree \\
\hline Social media aid communication between students and teachers outside school & 3.17 & .76 & Agree \\
\hline Social media can be used to teach all subjects in the classroom & 2.91 & .99 & Agree \\
\hline $\begin{array}{l}\text { Secondary school students rely on social media to do their assignment without } \\
\text { consulting other sources }\end{array}$ & 3.03 & .90 & Agree \\
\hline Students spends most of their time on social media for non-academic information & 3.02 & .89 & Agree \\
\hline Social media makes students exposed to ICT & 3.30 & .83 & Agree \\
\hline Social media improves students' creativity. & 3.05 & .84 & Agree \\
\hline Social media encourages knowledge sharing among students and teachers & 2.96 & .92 & Agree \\
\hline Social media helps students in choosing a career for themselves. & 3.02 & .88 & Agree \\
\hline Social media has become a useful tool for student research & 3.45 & .76 & Agree \\
\hline Cluster & $\mathbf{3 . 0 8}$ & $\mathbf{0 . 0 8}$ & \\
\hline
\end{tabular}

The result in Table-1 shows the mean ratings of the influence of social network on the academic performance of secondary school students in Benin Metropolis of Edo State. It further shows that the students agreed that: social media improves students' academic performance; social media enlightens students more about what is been taught in class; shy students use social media as an alternative means to voice their thoughts; social media aid communication between students and teachers outside school; social media can be used to teach all subjects in the classroom; secondary school students rely on social media to do their assignment without consulting other sources; students spends most of their time on social media for nonacademic information; social media makes students exposed to ICT; social media improves students' creativity; social media encourages knowledge sharing among students and teachers; social media helps students in choosing a career for themselves; and social media has become a useful tool for student research. The cluster mean of 3.08 and 0.08 implies that social network influences the academic performance of secondary school students to a high degree.

Research question 2: What are the dangers in secondary student's exposure to social media?

Table-2: Mean ratings of the dangers in secondary student's exposure to social media

\begin{tabular}{|l|l|l|l|}
\hline Items & Mean & $\begin{array}{l}\text { Standard } \\
\text { deviation }\end{array}$ & Remarks \\
\hline Social media contradicts what is been taught in the classroom & 2.52 & 1.06 & Agree \\
\hline Social media reduces the desire for classroom activities & 2.88 & .94 & Agree \\
\hline The use of social media has made student lazy to write & 2.83 & .98 & Agree \\
\hline $\begin{array}{l}\text { Students who spend more time on social are likely to perform poorly on academic } \\
\text { activity }\end{array}$ & 2.62 & 1.06 & Agree \\
\hline Social media promotes sexual immorality among secondary school students & 2.91 & .96 & Agree \\
\hline Students don't care if the information they get online is authentic or not. & 2.95 & .83 & Agree \\
\hline Social media has made verbal communication between students difficult & 2.54 & 1.00 & Agree \\
\hline $\begin{array}{l}\text { Students' accessibility to porn and dating site has caused poor cognitive/ mental } \\
\text { development. }\end{array}$ & 3.06 & .96 & Agree \\
\hline Participation in social media activity has made students not to think ahead. & 2.79 & .99 & Agree \\
\hline Trolling on social media has caused depression for students. & 2.70 & 1.03 & Agree \\
\hline The use of social media cost medical problem for students & 2.62 & 1.13 & Agree \\
\hline Social media participation has publicly humiliated students & 2.82 & .98 & Agree \\
\hline Social media has destroyed the reading culture of students & 2.68 & .97 & Agree \\
\hline $\begin{array}{l}\text { Social media communication has brought danger to the lives of secondary school } \\
\text { students. }\end{array}$ & 2.62 & 1.04 & Agree \\
\hline
\end{tabular}

The result in Table- 2 shows the mean ratings of the dangers in secondary student's exposure to social media. It further shows that the students agreed that Social media: contradicts what is been taught in the classroom; reduces the desire for classroom activities; make student lazy to write; makes students who spend more time on it to perform poorly on academic activity; promotes sexual immorality among secondary school students; make students not to care if the information they get online is authentic or not; has made verbal 
Imasuen Kennedy., J Adv Educ Philos, July, 2020; 4(7): 334-343

communication between students difficult. Others are: Students' accessibility to porn and dating site has caused poor cognitive/ mental development; participation in social media activity has made students not to think ahead; trolling on social media has caused depression for students; the use of social media causes mental problem for students; Social media participation has publicly humiliated students; and Social media communication has brought danger to the lives of secondary school students.

Research question 3: How many hours do students spend daily on social media?

Table-3: Frequency of the response on the number of hours students spend daily on social media

\begin{tabular}{|l|l|l|}
\hline Number of hours spent daily on social media & Frequency & Percentage \\
\hline $1-4$ hour & 167 & 29.0 \\
\hline $5-8$ hours & 322 & 56.0 \\
\hline $9-12$ hours & 72 & 12.5 \\
\hline Above 12 hours & 14 & 2.5 \\
\hline
\end{tabular}

The result in Table-3 shows the number of hours students spend daily on social media. It further showed that $29.0 \%$ of the students agrees that they spend between 1 and 3 hours daily using the social media network. $56.0 \%$ agrees that they spend between 5 and 8 hours daily using the social media network. $12.5 \%$ averred that they between 9 and 12 hours daily using the social media network; and $2.5 \%$ of the students agreed that they spend above 12 hours daily using the social media network.

Hypothesis 1: There is no significant difference in the academic performance of students who use the social media and those who do not in Benin Metropolis of Edo State.

Table-4: Independent sample $t$ test of the difference in the academic performance of students who use the social media and those who do not in Benin Metropolis of Edo State

\begin{tabular}{|l|l|l|l|l|l|l|l|l|}
\hline \multicolumn{2}{|l|}{ Academic performance } & N & Mean & Standard Deviation & df & t & P value & Remarks \\
\hline \multirow{2}{*}{ Social media usage } & Did not use & 89 & 47.53 & 7.598 & $573-2.473$ & 0.014 Significant \\
\cline { 2 - 6 } & Use & 486 & 50.39 & 5.92 & & & \\
\hline
\end{tabular}

The result in Table-4 showed the value of 2.473 and a $\mathrm{p}$ value of 0.014 . Testing at alpha level of 0.05 , the $\mathrm{p}$ value is lesser than the alpha level. Therefore, the null hypothesis which states that "there is no significant difference in the academic performance of students who use the social media and those who do not in Benin Metropolis of Edo State" is rejected. Consequently, there is a significant difference in the academic performance of students who use the social media and those who do not in Benin Metropolis of Edo State. The academic performance of students who use the social media network seem to be better than those who never use it.

Hypothesis 2: There is no significant difference between male and female student usage of social media network.

Table-5: Independent sample t test of the difference between male and female secondary school student usage of social media network

\begin{tabular}{|l|l|l|l|l|l|l|l|l|}
\hline \multicolumn{2}{|l|}{ Social media usage } & N & Mean & Standard Deviation & df & t & P value & Remark \\
\hline \multirow{2}{*}{ Sex } & Male & 296 & 89.02 & 10.47 & 5733.439 & 0.001 Significant \\
\cline { 2 - 6 } & Female & 279 & 86.86 & 9.26 & & & \\
\hline
\end{tabular}

The result in Table-5 showed a $t$ value of 3.439 and a $\mathrm{p}$ value of 0.001 . Testing at alpha level of 0.05 , the $\mathrm{p}$ value is lesser than the alpha level. Therefore, the null hypothesis which states that "there is no significant difference between male and female student usage of social media network" is rejected. Consequently, there is a significant difference between male and female student usage of social media network. The male students seem to use the social media network than the female students.

\section{DISCUSSION OF FINDINGS}

The findings first and foremost revealed that senior secondary students in Benin Metropolis are well exposed to social media networks; $84.5 \%$ of respondents use one social media platform or the other. They are on Facebook and whatsApp. Other major social media platforms used by the students are twitter, instagram and Youtube. This corroborates the findings of Wiley and Sisson [36], that more than $90 \%$ percent of tertiary school students use social networks. The findings also revealed that social network influences the academic performance of secondary school students to a high degree. This is in agreement with Young [37], 
Imasuen Kennedy., J Adv Educ Philos, July, 2020; 4(7): 334-343

who opined that the internet expands its reach to teenagers' school life. Young noted that students are more reliant on the internet to access information that is involved in their school life as well as entertainment. The social media aids their communication process in the school and boost their study facility through chatting with friends outside school and browsing assignment. According to Deng and Tavares [21], social media help students to think clearly and this helps them to make wise decisions in their day-to-day lives. On their part, Apeanti and Danso [22], averred that students felt that their grades would be better if they can contact professors openly through social media to get their doubts clarified. Yunus and Salehi [23] pointed out that, social media use enhanced students' vocabulary and writing ability, thereby enhancing their academic performance

However, Paul, Baker and Cochran [24], opined that the time spent on social media was dependent on the attention span of the students. Attention span according to them is the amount of time for which students can concentrate on their study without getting distracted. They found out that, higher the attention span, lower is the time spent by students on social media. On his part, Junco [25], posited that time spent on Facebook was very strongly negatively related to the overall GPA of the students. Kirschner and Karpinski [26] found out that, over indulgence with social media can affect students' academic performance negatively.

In response to the dangers inherent in social media, the students agreed that there are dangers in their exposure to social media usage. This is in line with Adrien Grey [38] who believed that student's addictiveness to social media has highly affected them emotionally, psychologically \& academically due to the lack of privacy, time consumption, socialization, civilization and so on. Young [37] also asserts that social media like Facebook is majorly used for entertainment, Social media has destroyed the reading culture of students and promotes sexual immorality among secondary school students. Students no longer care if the information they get online is authentic or not. Davies and Cranston [28], posited that social media brings about criminal activities such as identity theft and fake contacts which is prevalent today, sexual abuse or harassment and unsuitable advertising. On the same subject O'keeffe and Clakepearson [29], also mentioned cyberbullying, online harassment, sexting, face book depression, and privacy concerns as some of the danger associated with social networking.

With regards to time spent on so social media, out of the 575 students; $167(29.0 \%)$ spent 1 hour to 4 hours, $322(56.0 \%)$ spent 5hours to 8 hours, $72(12.5 \%)$ spent 9 hours to 12 hours and $14(2.5 \%) 12$ hours and above. It can be deduced that majority of the students; $(87.5 \%)$ spent over five (5) hours on social media on a daily basis and this comes with implications as it was earlier revealed by the study conducted by Kirschner and Karpinski [26], that over-involvement or obsession with social networking sites (SNSs) by students can have negative impacts on their academic performance. Mingle and Adams [27], in their study on the social media effect on grade performance, Likert scale was used to survey amongst 526 students. Out of these 526 students, majority confirmed that the use of social media affected their grades negatively. 62 (11.8\%) students strongly agreed, while a majority of students of strength $255(48.5 \%)$ agreed that their grades dropped owing to the use of social media. In addition, 60 $(11.4 \%)$ students neither agreed nor disagreed. Finally, $(8.2 \%)$ and $106(20.2 \%)$ students disagreed and strongly disagreed respectively that their grades dropped, due to the use of social media.

\section{CONCLUSION}

It is without doubt that social media is and will remain an important tool in human life as far as communication is concerned. Today mankind is harvesting tremendously from its existence not only in mere communication point of view but also in most scholarly activities. Different forms of education including distance education has been widely patronized and facilitated to some degree through these social media networks. Acquiring information both locally and internationally from friends, lecturers or experts is no longer a struggle as compared to the olden days, and the internet is the ultimate master behind this success. Social media is 'a useful servant but dangerous master' and can be also be described as 'a two edge sword' and as such, users especially secondary school students must be alert about its dangers and be prudent in its utilization.

The nature of social media as a useful servant but a dangerous master and a two edge sword has been revealed in the findings of the study that, despite the benefits that students can harness from the social media networks such as improving creativity, enlightening students more on what is being taught in class, encouraging knowledge sharing among students and teachers, building relationship, among others, there is to some extent addiction and distraction of attention caused by the use of social media which could have serious consequences on the academic life of students.

\section{RECOMMENDATION}

In the light of the findings the following recommendations are made:

- Students should be enlightened to pay minimal attention to social media and focus more on their academic activities

- Teachers should be encouraged to interact with the students on Social Media sites for instance having a group Whatsapp platform where they can exchange views about a particular subject 
even when they are on holiday. This will in turn encourage them to use social media positively.

- The creation of awareness on applications that are academically oriented, so that the students can utilize them whenever they are online such as evernote, goggle drive, drop box, eBooks among others.

- Students should be enlightened on how to manage their time on social media to avoid addiction and to make them focus more on academics instead of entertainment.

- Parents on the other hand should try and monitor their wards usage of social media to avoid using it for illicit act since it has privacy.

\section{REFERENCES}

1. Asemah, E. S., \& Edegoh, L. O. (2012). New media and political advertising in Nigeria: Prospects and challenges. African Research Review, 6(4), 248-265.

2. Boyd, D. M., \& Ellison, N. B. (2007). Social network sites: definition, history and scholarships. Journal of computer-mediated communication, 13(1):210-230.

3. Williams, K., Boyd, A., Densten, S., Chin, R., Diamond, D., \& Morgenthaler, C. (2009). Social networking privacy behaviors and risks. Seidenberg School of CSIS, Pace University, USA.

4. Kietzmann, H. (2012). Social media? Get serious! Understanding the functional building blocks of social media. Business Horizons. 54:241-251.

5. Kaplan, A. M., \& Haenlein, M. (2010). Users of the world, unite! The challenges and opportunities of Social Media. Business horizons, 53(1):59-68.

6. Sorav, J. (2010). Most Popular Social Networking Sites of the World. Retrieved 27 March 2018 http://socialmediatoday.com/soravjain/195917/40most popular-social networking- sites-world, 2010.

7. Pompeo, E., Rogliani, P., Tacconi, F., Dauri, M., Saltini, C., Novelli, G., ... \& Awake Thoracic Surgery Research Group. (2012). Randomized comparison of awake nonresectional versus nonawake resectional lung volume reduction surgery. The Journal of Thoracic and Cardiovascular Surgery, 143(1), 47-54.

8. Roblyer, M. D. (2010). Findings on Facebook in higher education: A comparison of college Faculty and student uses and perceptions of social networking sites. Internet and Higher Education. 13:134-140.

9. Rapacki, S. (2007). Social networking sites: Why teens need places like Myspace. Young Adult Library Services. 28-30.

10. Kyoshaba, M. (2009). Factors affecting academic performance of undergraduate students at Uganda Christian University (Doctoral dissertation, Makerere University).
11. Hoyle, G. (1986). Glial cells of an insect ganglion. Journal of Comparative Neurology, 246(1), 85-103.

12. Andreas M., \& Haenlein, M. (2010). Users of the world, unite! The challenges and opportunities of social media. Business Horizons. 53(1):61.

13. Nelson, P. T., Alafuzoff, I., Bigio, E. H., Bouras, C., Braak, H., Cairns, N. J., ... \& Duyckaerts, C. (2012). Correlation of Alzheimer disease neuropathologic changes with cognitive status: a review of the literature. Journal of Neuropathology \& Experimental Neurology, 71(5), 362-381.

14. Kist, W. (2012). Class get ready to tweet: Social media in the classroom. Our children. Retrieved from http://files.eric.ed.gov/fulltext/EJ991339.pdf.

15. Moran, M., Seaman, J., \& Tinti-Kane, H. (2012). How today's higher education faculty use social media. Retrieved from http://www.pearsonlearningsolutions.com /pdfs/Pearson-social-media survey-2012-color.pdf.

16. Sherer, P., \& Shea, T. (2011). Using online video to support student learning and engagement. College Teaching, 59(2), 56-59.

17. Eick, C. J., \& King, D. T. (2012). Non-science majors' perceptions on the use of YouTube video to support learning in an integrated science lecture. Journal of College Science Teaching, 42(1), 26-30.

18. Greenfield, P., \& Subrahmanyam, K. (2008). Online communication and adolescent relationships. The Future of Children, 18, 119. 140. Retrieved from: http://www.futureofchildren.org.

19. Olubiyi, S. (2012). Social media and Nigeria Youth burden. Retrieved December, 12, 2013.

20. Obi, N. C., Bulus, L. D., Adamu, G. M., \& Sala'at, A. B. (2012). The need for safety consciousness among Youths on social Networking Sites. Journal of Applied Science and management (JASM), 14(1).

21. Deng, L., \& Tavares, N. J. (2013). From Moodle to Facebook: Exploring students' motivation and experiences in online communities. Computers \& Education, 68, 167-176.

22. Apeanti, W. O., \& Danso, E. D. (2014). Students' use of social media in higher education in Ghana. Innovative Journal, 3(1), 3-9.

23. Yunus, M. M., \& Salehi, H. (2012). The effectiveness of Facebook groups on teaching and improving writing: Students' perceptions. International journal of education and information Technologies, 1(6), 87-96.

24. Paul, J., Baker, H., \& Cochran, J. (2012). Effect of online social networking on student academic performance. Retrieved from https://digitalcommons.kennesaw.edu/ facpubs/3149/

25. Junco, R. (2011). Too much face and not enough books: The relationship between multiple indices 
of Facebook use and academic performance. Retrieved from https://reyjunco.com/wordpress/pdf/JuncoCHBFac ebookGrades.pdf

26. Kirschner, P., \& Karpinski, A. (2010). Facebook and academic performance. Computers in Human Behavior, 26, 1237-1245. Retrieved from http://personal.denison.edu/ $\sim$ matthewsn/facebook\%20and\%20academic $\% 20 p$ erformance.pdf

27. Mingle, J., \& Adams, A. (2015). Social Media Network Participation and Academic Performance in Senior High Schools in Ghana. Retrieved from https://

digitalcommons.unl.edu/cgi/viewcontent.cgi?articl $\mathrm{e}=3446 \&$ context $=$ libphilprac

28. Davies, T., \& Cranston, P. (2008). Youth work and social Networking. Final research report. How youth can work best to support young people to navigate the risks and make the most of the opportunities of online social networking? National youth agency and research. Retrieved from http://www.nya.org.uk/resource/youth-worksocial-networking.

29. O’Keeffe, G. S., \& Clake-pearson, K. C. (2011). The impact of social media on children, Adolescents and families. American Academy of Peadiatrics. Retrieved from pediatrics.aappublications.org.

30. Lin, G., \& Subrahmanyam, K. (2007). Adolescents and the net: Internet use and wellbeing. Adolescence, 42(168), 659-675. Retrieved from: http://findarticles.com/ p/articles/ mi_m2248/is_16842/ai_n27483301/

31. Giles \& Price, 2008
32. Bonds-Raacke, J., \& Raacke, J. (2008). Myspace and Facebook: Applying the uses and gratifications theory to exploring friendnetworking sites. Cyber Psychology and Behavior, 11:169-174.

33. Strauss, K., Griffin, M. A., \& Rafferty, A. E. (2009). Proactivity directed toward the team and organization: The role of leadership, commitment and role- breadth self- efficacy. British Journal of Management, 20(3), 279-291.

34. Merten, M., \& Williams, A. (2009). Adolescents' online social networking following the death of a peer. Journal of Adolescent Research, 24, 67-90.

35. Peter, J., \& Valkenburg, P. (2009). Social consequences of the internet for adolescents: A decade of research. Psychological Science, 18(1), $1-4$.

36. Wiley, C., \& Sisson, M. (2006, November). Ethics, accuracy and assumption: The use of Facebook by students and employers. In Southwestern Ohio Council for Higher Education Special Topics Forum, Dayton, $\mathrm{OH}$ (pp. 227-238).

37. Young, B. (2006). A study of the effect of internet use on social capital on the academic performance. Retrieved from isdpt.org/isdpt.publication/journals. Accessed 03/04/2013.

38. Herbert, M. R., Ziegler, D. A., Deutsch, C. K., O’brien, L. M., Lange, N., Bakardjiev, A., ... \& Kennedy, D. (2003). Dissociations of cerebral cortex, subcortical and cerebral white matter volumes in autistic boys. Brain, 126(5), 11821192. 